\title{
Loan Loss Reserves (LLR), Expected Loss (EL), and Value at Risks (VaR)
}

\author{
Mohd Yaziz Mohd Isa \\ Universiti Tun Abdul Razak, Kuala Lumpur, Malaysia \\ Yap Voon Choong, David Yong Gun Fie \\ Multimedia University, Selangor, Malaysia \\ Md. Zabid Hj. Abdul Rashid \\ Universiti Tun Abdul Razak, Kuala Lumpur, Malaysia
}

\begin{abstract}
This paper clarifies the distinctions between loan loss reserves (LLR), expected loss (EL), and loan loss provisions (LLP). The paper also includes information on individual and collective impairment assessment of local commercial banks in Malaysia collected from their annual reports. Most banks have maintained collective assessment (CA) allowance ratio of lower than $1.2 \%$ of gross total loans.
\end{abstract}

Keywords: collective assessment (CA), loan loss reserves (LLR), value at risk (VaR)

\section{Introduction}

From January 1, 2012, the Bank Negara Malaysia (BNM) (the Central Bank of Malaysia) imposed impairment assessment and provisioning to comply with individual or collective assessment (CA). In the latest circular, all banks are required to set aside a minimum of $1.2 \%$ of the gross total loans for CA effective on December 31, 2015. This paper clarifies the distinctions between loan loss reserves (LLR), expected loss (EL), and loan loss provisions (LLP). The paper also includes information on individual and collective impairment assessment of local commercial banks in Malaysia.

EL

Hlawatsch and Ostrowski (2010) wrote about previous studies in quantifying uncertainty in repayments in the context of credits by Cyert and Trueblood (1957) and Cyert, Davidson, and Thompson (1962). In the study by the latter, they estimated the loss expectancy rates, using probabilities of transition between different categories of retail debts from aging account receivables of a department store. Subsequently, Kim and Santomero (1993) adopted this approach to quantify uncertainty in repayments of bank loans. Beattie, Casson, Dale, McKenzie, Sutcliffe, and Turner (1995) documented a comprehensive overview on the determinants of LLP. They are regarded as precursors of the concept of EL.

Mohd Yaziz Mohd Isa, assistant professor, Bank Rakyat School of Business \& Entrepreneurship, Universiti Tun Abdul Razak. Email: mohd_yaziz@unirazak.edu.my.

Yap Voon Choong, senior lecturer, Faculty of Management, Multimedia University.

David Yong Gun Fie, associate professor, Faculty of Management, Multimedia University.

Md. Zabid Hj. Abdul Rashid, president and vice-chancellor, Universiti Tun Abdul Razak. 
The original purpose of LLP is the transmission of risk precaution for banks. However, due to two major regulatory changes (the adoption of the IAS 39 and the implementation of the Basel II Accords ${ }^{1}$ ). The purpose of the LLP now includes providing information to bank regulators, investors, creditors, and policy-makers.

In addition, currently, the focus of studies on LLP is to determine whether it has succeeded in mitigating the discretionary components of the LLP and strengthening the reliability of financial statements by accurately reflecting the credit losses expected to occur. This is captured in Table 1 below.

Table 1

Current Focus of Studies on LLP

\begin{tabular}{|c|c|}
\hline The objectives of the regulatory changes & $\begin{array}{l}\text { Users of financial } \\
\text { statements }\end{array}$ \\
\hline $\begin{array}{l}\text { Through the adoption of IAS } 39 \text { and Basel II Accord, the loan loss provisioning practices now seek to } \\
\text { become more forward-looking and to increase the reliability of financial statements. }\end{array}$ & Bank regulators \\
\hline $\begin{array}{l}\text { Current focus of studies: Whether it has succeeded in mitigating the discretionary compc } \\
\text { strengthening the reliability of financial statements by accurately reflecting credit losses }\end{array}$ & $\begin{array}{l}\text { investors, creditors, } \\
\text { and policy-makers }\end{array}$ \\
\hline
\end{tabular}

The implementation of the Basel II Accords Pillar 12004 is intended by banking regulators to ensure that banks have adequate minimum capital of $8 \%$ for the credit risk they exposed themselves to through lending activities. It is meant to safeguard the solvency of banks and the overall economic stability. Further, the Basel II Accord permits banks to adopt either of the two methods in assessing credit risk; the standardized approach and the internal ratings-based (IRB) approach. The Basel II has now been extended and effectively superseded by Basel III, which was introduced in 2010 and targeted for full implementation by 2019. The latest Basel III seeks to further strengthen banks' capital not only through holding minimum capital but also by strengthening the quantity, quality, consistency, and reliability of the capital. Malaysian banks have started embracing the Basel III Accord since January 2013.

\section{Value at Risks (VaR) of Banks}

The difference between LLP and LLR is that the latter is the amount that the bank creates and which represents the amount the bank thought to be adequate and reasonable to cover the losses that are expected to occur in its loan portfolio.

In addition, the occurrence of default may be categorized into two classes. Firstly, it is the default attributable to the different economic or commercial activities that involves different levels of risk that the borrowers face, and the risk is being translated into non-performing loans through default. Secondly, it is wilful default, where the borrower does not repay the loan even though it is possible for the borrower to do so.

LLP, non-performing loans, and LLR are the main indicators of banks' asset quality. LLP and LLR are two different concepts. The LLR is a prudential regulatory and supervisory concept. It is to ensure that banks established LLP at a level commensurate with the level of risks in their loan portfolio. This is a portion of a bank's cash or cash equivalents holdings, set aside to cover the estimated potential losses in loans portfolio. When loans are repaid, this reserve account shrinks accordingly, as there is less need to hold the reserves. On the other hand, when loans are made, it increases accordingly as there is a need to hold more reserves. In the event of defaulted loans, collateral is liquidated and the proceeds from the disposal of the collateral are credited to LLR.

\footnotetext{
${ }^{1}$ Subsequently superseded by Basel III that was introduced in 2010 to ensure that banks remain strongly capitalized and have enough liquidity to face any future financial crisis. The Basel III framework is to be implemented progressively across different countries until 2019.
} 
Additionally, the approaches are different for LLP and LLR. In the former, it is in terms of accounting practices where provisioning for loan losses plays a key role in determining the makeup and thus, the transparency and representation of faithfulness of a bank's balance sheet (Carlin, Finch, \& Ford, 2009). In contrast, for the latter, it is in terms of regulatory perspective where decisions are made with respect to reserves for loan losses that have the capacity to wield against substantial influence over the level of volatility and cyclicality evident in reported bank earnings.

A loss given default (LGD) refers to the estimated amount of loss expected if a loan defaults. The LGD is determined by several characteristics of the loan transactions, such as collateral, seniority of claims and guarantees. Further, in certain cases where the loans are well secured - for instance by a landed property, which does not depreciate much — upon the default, it may not necessarily lead to loan loss. It may even be more than adequate to cover any loan balances plus related handling costs.

An exposure at default (EAD) is a borrower's loan exposure at the time of default. The estimate of the likelihood of the borrower defaulting on its obligation which is characterized by the borrower's risks is the probability of default (PD).

The product of PD multiplies by LGD multiplies by EAD is the potential credit loss. These are the three main variables affecting the credit risk of a loan. They indicate an EL and their volatilities determine an unexpected loss.

The differences between the LLP and the EL are due to different approaches regarding parameter estimates. Whilst in the LLP, banks create the provisions when a default event has occurred, that is when the borrower fails to meet the repayment; the EL is created at the initiation of the loan to denote the expected amount of the loan that would be lost in the case of a default. Banks compute the EL yearly. As such, the EL account is for a period of one year, while the LLP considers the whole maturity period of the loan.

Further, banks may choose to write-off bad loans that cannot be collected instead of letting them to accumulate to clean their books. By such means, it may also provide investors, creditors, regulators, and policy-makers with additional confidence in the reported figures of bad loans. When it comes to disclosure of the information on LLP, it is usually accompanied by the disclosure of other indicators of loan default, such as changes in the levels of non-performing loans and loans write-offs, so that any excess level of the LLP will have positive effects.

The EL and the unexpected loss are components of VaR for all banks. The VaR is critical in defining the level of bank capital and LLR that is necessary to achieve protection for the banks from insolvency.

The LLR and the LLP are two distinct concepts. The LLP reflects the flow of expenses in the income statement, whereas the former refers to a stock on the balance sheet. Often, the two concepts are lumped together under the broad heading of loan loss provisioning.

The LLR is created against the possibility of future losses. The portion of loan principal that is not expected to be paid back is deducted from total loans. According to Walter (1991), the LLR is also called the allowance for loan losses, or reserves for credit losses. In Malaysia, commercial banks termed it as "allowance for impaired loans”, and it is individually or collectively assessed.

Currently, in Malaysia, there is no minimum requirement as banks are allowed to set the CA rate, and where individually assessed loans for impairment do not result in impairment provisions, banks would include in a group of loans those with similar credit risk characteristics for CA for impairment. While there is no minimum requirement set by BNM, most banks have maintained CA allowance ratio of lower than $1.2 \%$ of gross total loans. The impairment assessments of local commercial banks are tabulated in Table 2 below. 
Table 2

Individual Assessment and CA of Local Commercial Banks

\begin{tabular}{|c|c|c|c|}
\hline No. & Bank & Reporting date & RM ‘000 \\
\hline \multirow[t]{2}{*}{1} & \multirow[t]{2}{*}{ Maybank } & \multirow[t]{2}{*}{$31 / 12 / 2013$} & $\begin{array}{l}\text { Gross total loans }=242,358,759 \\
\text { Individual assessment }=1,502,010 \\
\mathrm{CA}=2,885,470(1.19 \%)\end{array}$ \\
\hline & & & Net loans $=\overline{237,971,279}$ \\
\hline \multirow[t]{2}{*}{2} & \multirow[t]{2}{*}{ CIMB } & \multirow[t]{2}{*}{$31 / 12 / 2013$} & $\begin{array}{l}\text { Gross total loans }=135,604,866 \\
\text { Individual assessment }=1,526,098 \\
\text { CA }=1,245,458(0.92 \%)\end{array}$ \\
\hline & & & Net loans $=\overline{132,833,310}$ \\
\hline \multirow[t]{2}{*}{3} & \multirow[t]{2}{*}{ Public Bank } & \multirow[t]{2}{*}{$31 / 12 / 2013$} & $\begin{array}{l}\text { Gross total loans }=183,555,427 \\
\text { Individual assessment }=79,765 \\
C A=1,071,089(0.58 \%)\end{array}$ \\
\hline & & & Net loans $=\overline{182,404,573}$ \\
\hline \multirow[t]{2}{*}{4} & \multirow[t]{2}{*}{ RHB Bank } & \multirow[t]{2}{*}{$31 / 12 / 2013$} & $\begin{array}{l}\text { Gross total loans }=97,564,045 \\
\text { Individual assessment }=723,024 \\
\text { CA }=1,088,121(1.11 \%)\end{array}$ \\
\hline & & & Net loans $=\overline{95,752,900}$ \\
\hline \multirow[t]{2}{*}{5} & \multirow[t]{2}{*}{ AMMB Berhad } & \multirow[t]{2}{*}{$31 / 3 / 2014$} & $\begin{array}{l}\text { Gross total loans }=89,288,513 \\
\text { Individual assessment }=167,552 \\
\text { CA }=1,950,384(2.18 \%)\end{array}$ \\
\hline & & & Net loans $=\overline{87,170,577}$ \\
\hline \multirow[t]{2}{*}{6} & \multirow[t]{2}{*}{ Affin Bank } & \multirow[t]{2}{*}{$31 / 12 / 2013$} & $\begin{array}{l}\text { Gross total loans }=30,634,622 \\
\text { Individual assessment }=189,117 \\
\mathrm{CA}=266,595(0.87 \%)\end{array}$ \\
\hline & & & Net loans $=\overline{30,178,910}$ \\
\hline \multirow[t]{2}{*}{7} & \multirow[t]{2}{*}{ Hong Leong Bank } & \multirow[t]{2}{*}{$\begin{array}{l}\text { 30/9/2014 } \\
\text { (unaudited) }\end{array}$} & $\begin{array}{l}\text { Gross total loans }=89,504,072 \\
\text { Individual assessment }=416,569 \\
\mathrm{CA}=887,386(0.99 \%)\end{array}$ \\
\hline & & & Net loans $=\overline{88,200,117}$ \\
\hline \multirow[t]{2}{*}{8} & \multirow[t]{2}{*}{ Alliance Bank } & \multirow[t]{2}{*}{$31 / 3 / 2014$} & $\begin{array}{l}\text { Gross total loans }=32,229,446 \\
\text { Individual assessment }=97,159 \\
C A=313,296(0.97 \%)\end{array}$ \\
\hline & & & Net loans $=\overline{31,818,991}$ \\
\hline
\end{tabular}

Note. Source: Banks’ annual reports.

In BNM's latest circular, all banks are required to set aside a minimum of $1.2 \%$ of gross total loans for the CA effective from December 31, 2015.

While LLP is an expense account in the income statement, the LLR is a balance sheet account. The LLR appears on the asset side of a bank's balance sheet as a deduction from total loans. The total loans balance is reduced through a charge to the LLR. The total loans less the LLR, is called net loans (that is, net realizable value of the loans portfolio).

In their paper on provisioning policies among Chinese commercial banks, Curcio, Dyer, Gallo, and Gianfrancesco (2014) estimated that both levels were generally higher now than previously and were attributable to improved credit risk assessment since the Asian financial crisis. Why do banks create the LLR? Banks create LLR because displaying gross total loans on a bank's balance sheet as the amount of funds lent without an adjustment for expected but uncertain future losses would be overstating the bank's assets. 


\section{Conclusion}

Effective from January 1, 2012, the BNM (the Central Bank of Malaysia) imposed impairment assessment and provisioning to comply with individual assessment or CA. In the latest circular, all banks are required to set aside a minimum of $1.2 \%$ of the gross total loans for CA (the formulae being CA balance over gross total loans net of individual assessment balance, based on their own risk assessment of PD and LGD under FRS 139, which came into effect in financial year 2010). The 1.2\% CA rate would be effective on December 31, 2015.

The move to require the minimum CA rate of $1.2 \%$ effective on December 31, 2015 is to ensure an adequate level of collective impairment, in keeping pace with strong credit growth as currently experienced in Malaysia. Although at many banks, the reserves are divided into two categories, specific or allocated reserves and general reserves, for financial reports however, general and specific reserves are combined and simply reported as LLR.

\section{References}

Beattie, V. A., Casson, P. D., Dale, R. S., McKenzie, G. W., Sutcliffe, C. M. S., \& Turner, M. J. (1995). Banks and bad debts: Accounting for loan losses in international banking. Chichester: John Wiley \& Sons.

Carlin, T. M., Finch, N., \& Ford, G. W. (2009). The financial crisis and loan impairment provisioning in Asian banks. In G. N. Gregoriou (Ed.), The banking crisis handbook (pp. 335-352). Boca Raton, FL: CRC Press.

Curcio, D., Dyer, D., Gallo, A., \& Gianfrancesco, I. (2014). Determinants of banks' provisioning policies during the crisis. Managerial Finance, 40(10), 987-1006.

Cyert, R. M., \& Trueblood, R. M. (1957). Statistical sampling techniques in the aging of accounts receivable in a department store. Management Science, 3(2), 185-195.

Cyert, R. M., Davidson, H. J., \& Thompson, G. L. (1962). Estimation of the allowance for doubtful accounts by Markov chains. Management Science, 8(3), 287-303.

Hlawatsch, S., \& Ostrowski, S. (2010). Economic loan loss provision and expected loss. BuR Business Research Journal, 3(2), 133-149.

Kim, D., \& Santomero, A. M. (1993). Forecasting required loan loss reserves. Journal of Economics and Business, 45(3-4), 315-329.

Walter, J. R. (1991). Loan loss reserves. Economic Review, 77, 20-30. 